\title{
GENERAL SAFETY CONCEPTS USED IN TRANSPORT
}

\author{
Andrzej Szymanek ${ }^{1}$ (10 \\ ${ }^{1}$ Kazimierz Pulaski University of Technology and Humanities in Radom, Faculty of Transport, Electrical Engineering and Computer Science, \\ Malczewskiego 29, 26-600 Radom, Poland, email: a.szymanek@uthrad.pl, https://orcid.org/0000-0002-6983-3444
}

Reviewed positively: 09.11.2021

Information about quoting an article:

Szymanek A. (2020). General safety concepts used in transport. 2(4), 177-190, ISSN 2658-1698, e-ISSN 2658-2120, DOI: $10.24136 /$ tren.2020.013

Abstract - The article presents selected concepts, models and theories of safety known from research and applications in various areas of technology and suitable for use in the field of transport. In particular, attention was paid to cognitively promising in the field of transport safety, and relatively little used research concepts here: Normal Accident Theory (NAT) Ch.Perrow, "Swiss cheese model" /SCh-M/ by J. Reason, concepts of "safe space of action" by J. Rasmussen and R. Amalberti, the concept of High Reliability Organizations /HRO/, or even interpretations of the transport system as a complex system (CS).

The main aim of the article was to present some important general safety concepts and show that they can be used to model safety in the field of transport. The article shows that the so-called Geysen's thesis allows for the development of justified safety analogies between transport systems and such systems of technology that have greater scientific and engineering achievements in the field of safety.

Key words - safety concepts, transport systems, Normal Accident Theory (NAT), "Swiss cheese model", safe space of action, High Reliability Organizations, complex systems

JEL Classification - C02, C65, R41

\section{INTRODUCTION}

Safety is a multiaspective category, but it is always accompanied by the concepts of loss and risk. Safety is a characteristic of a system (technical object, process, decision-making situation) expressed by its ability to avoid loss. The term loss refers to various undesirable events of the type: disruption, incident, accident, disaster. Terms associated with the concept of loss, but in the aspect of technical reliability, are: malfunction, imperfection, failure, damage. Risk is associated with terms of threat and a sense of threat that are related to the perception of risk.

The differences in interpretation of the safety of the facility are due to the type of losses considered. For many researchers, the concept of safety refers to the losses of each element of the system "Human factor-Technology-Environment" (HF-T-E). According to others, only losses of life and health of the human factor in the process of task realization should be included in the definition of facility safety. Economic, ecological, and any other losses can be included in safety analyses when they affect the reduction of human life expectancy.
Here are three of the many interpretations of safety in technology (valid in transportation as well):

1. Safety, is a risk-adverse concept; thus, an object is more safe when it generates less risk of loss [1].

2. The safety of a HF-T-E system is its ability to accomplish its purpose (task) without loss of human life or health [2]. This definition is limited to cases where the system is operated in accordance with regulations. It is not suitable where - in real systems (transport) - regulations, procedures, instructions are not respected, or are broken?

3. Safety is an emergent feature of a system, understood as its ability to:

a) maintain important system properties, such as integrity, stability, self-stability, competitiveness;

b) provide important system behaviors, such as adaptation, homeostasis, growth, learning, equifinality, intentionality.

Another group of terms associated with the concept of safety are the events that make up the accident chain. Here are some definitions [3]. 
1. Dangerous event: an event that has the potential to cause harm.

2. Disturbance (disruption): an unwanted, unexpected and time-limited event (interrupted operation) within a specific technical system.

3. Incident: Unexpected, time-limited event within a defined technical system in which the possibility of an exposure to a hazard cannot be excluded.

4. Accident: an unexpected, time-limited event involving risk to health, disability, or damage to objects. An accident - like near-accidents and unsafe behaviors - is one symptom of failure of the system in which accidents occur.

A specific level of safety is achieved through safety management - which is accomplished through cyclical risk management processes. Safety management is management by objectives, i.e. management with a systemic character. It is a process presented as a chain of activities in which each cycle is an improvement (control) of the previous state. This "circularity of action" to improve safety is an implication of the "four purposes strategy":

1. danger elimination,

2. danger control,

3. accident prevention,

4. accident cost minimization.

This safety management model requires a system approach. Safety management requires a safety strategy, which defines the principles of the management style and is close to a safety policy.

\section{SOME COMMENTS ON SAFETY MODELING}

It is difficult to map the most important relationship in safety research: "cause $\rightarrow$ accident" or the "symptom of danger $\rightarrow$ an accident" relationship, which is essential for diagnosis. It is also difficult to quantify the risk resulting from these relationships, as well as to determine the prognosis and genesis of accidents. This is primarily because hazardous events are the product of different hazard mechanisms. It is also a very difficult problem to model the hypothetical frequency (sometimes the regularity is more important) of occurrence of hazardous events. The most commonly used measure is probability and its statistical evaluations. In the case of risk assessment in the decision-making process it is reasonable to base on the personalistic concept of probability.

Accidents are repetitive events. They have their causes. It is therefore important to predict and genesis these events.
Phenomenological models created for isolated classes of systems and potentially hazardous phenomena will be applied in modeling threat mechanisms. Decision-making models (including optimization models) are appropriate for risk studies and safety control in medium and large scale engineering systems. Predictive models should find application in forecasting accident numbers and in studying accident trends. Normative models would have applications in work safety management and the design of "safe" manufacturing systems, transportation systems, and operating systems.

The nature of safety issues is such that in their modeling correlation models are more applicable than causal models. Correlation models created on the basis of observed or hypothetical correlations between phenomena or features of the system under study can be used as predictive models of safety. In this case, making "correlation hypotheses" is as much a matter of knowledge of the phenomenon as intuition of the researcher.

In modeling and researching transportation safety, one can use broad analogies and parallels to research concepts that have arisen in various areas of technology. Here is a synthetic presentation of selected security concepts and theories that can be postulated for use in transportation safety modeling and research [3-4].

\section{THEORIES OF THE CHAIN OF EVENTS}

Chain of events theories were built to explain the causes and processes of industrial accidents. The earliest were developed in the 1930s; these were attempts to build theoretical models of accident causality, among which chain of events theory explained accidents through a " sequence of events" [5-6].

Much inspiration came from the domino theory proposed in 1931 by H. W. Heinrich, [7-8]. It was the first scientific concept for modeling accidents in industry (Fig. 1).

Other researchers L.F. Bird and E. Adams developed more complete domino theories. According to them, the most important accident generating factors are those related to management. Later, other theories of accident genesis were developed: the theory of multilinear sequences of events, the theory of gradual genesis and the chain of extensional events, and several others. The above concepts were merged by the theory of accident causality based on the lack of management [9]. 


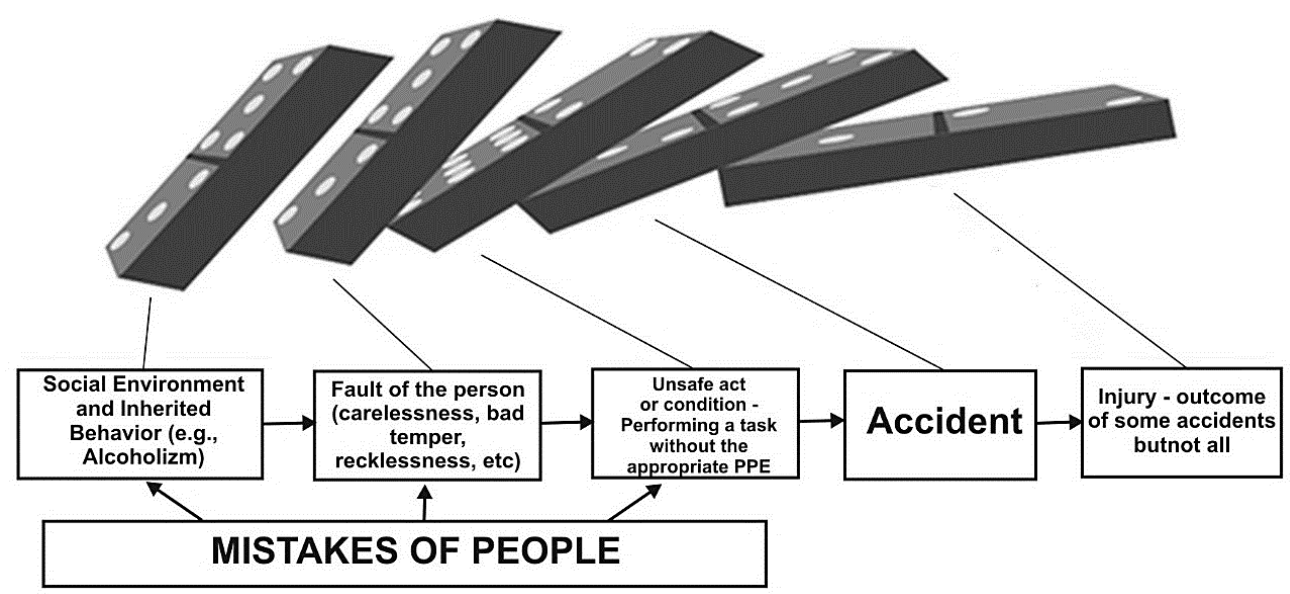

Fig. 1. Domino model of accident causation [7]

The analysis of industrial accidents made it possible to formulate axioms that can provide directions for the study of transport accidents; we will write them in the interpretation of the transport system, i.e. a system with the syntax HF - human factor (driver, passenger, pedestrian); MT (means of transport), TI (transport infrastructure), CE (closer environment - affecting traffic processes, traffic control processes, initialfinal processes). Here are the axioms:

1. Components of the HF-MT-TI-CE system are the main causes of accident occurrence.

2. An accident occurs when a threat in the system reaches a critical value.

3. An accident usually has multiple causes that are not necessarily correlated with each other.

4. More causes of an accident are less likely to occur.

5. An accident is usually preceded by events called precursor, omen.

6. Every accident is the result of "out of control" management.

7. The primary way to prevent accidents is to improve management in HF-MT-TI-CE systems.

8. The best safety improvement comes from early prevention.

A common thesis can be applied to these principles: accidents are the result of "safety management system weaknesses." The key to effective management is the ability to define and locate these weaknesses [10].

\section{COINCIDENCE OF INDEPENDENT RISK FACTORS AND ACCIDENTS}

The concept is based on the following hypothesis: the spatial-temporal concurrence of certain independent events must lead to an accident; thus, an accident is the result of the "superposition" of independent factors (events).

In the safety literature, we find various connotations of this hypothesis, and a frequently used term is coincidence. There is no good theory to explain the role of coincidence as a source of accident occurrence. Related theories are: H. Hepburn's "branching event chain theory" or Andriesen's multi-causality hypothesis. Usually the sequence of events leading up to an accident is as follows:

coincidence $\rightarrow$ incident $\rightarrow$ conflict $\rightarrow$ near accident $\rightarrow$ accident

If the hypothesis that each accident is the final event of a certain sequence of events were true then there are opportunities to develop preventive activities. Hence, in theories of this type such concepts have appeared as, for example: "chain accident", which causes subsequent accidents; "crossover accidents" (crossing of several activities in one place and time); "telescope accident", where disorder and accident occur almost at the same moment. Note that perhaps except for "telescope accidents," the other types of accidents occur in traffic.

Basic mechanisms of defence against accidents originating from coincidence of events require prediction of development scenarios and control of potentially colliding factors. Depending on the nature of the considered system it is a control of: colliding streams of vehicles (transport), interfering with each other streams of information (communications), colliding technological operations (production organization). 


\section{JAMES REASON'S THEORY. HIDDEN HAZARDS AND ACTIVE ERRORS AS THE CAUSATIONS OF ACCIDENTS}

In the process of transportation management there are specific "gaps" and "excesses" of management, which are symptoms of countereffectiveness of this process. Improving the effectiveness of transport management and, in particular, transport accident risk management requires the development of a methodology for identifying such management gaps and excesses [10] In particular, management gaps can be interpreted as hidden necessary conditions for the occurrence of accidents in complex systems; also in transportation. Criteria for identifying management gaps can be looked for in the theory of J. Reason [11-12].

The primary tool for studying management gaps would be the J. Reason's Swiss Cheese Model (SChM), which is part of a broader concept of modeling risk management of so-called "organizational accidents" that arise in complex systems [12]. One of the theses of SChM can be formulated as follows: accidents are the effects of gaps in the management of a given system. In this model, the key factors are the so-called safety layers ("slices of cheese") with variously located "holes", i.e. gaps of two kinds: 1). Active faults; 2). Hidden conditions (so-called resident pathogens).
Reason believed that these gaps were the main causes of accidents.

Active errors - are incorrect behaviors and actions of the human factor in the system, as well as errors: omission, execution, procedural and misconduct. On the other hand, hidden (latent) threats are errors from the system design stage or errors in the implementation of management procedures. The main idea of SChM is this: when there is an overlap between a hidden threat with an active error - a gap is created, which is a necessary condition for an accident to occur.

In any real system, including transportation, safety layers are created, which are material (control systems, safety zones, etc.) or immaterial (regulations, standards, procedures). In order for a transportation accident to occur, gaps must appear simultaneously on each safety layer and create an abstract time-space sequence through which the accident trajectory will "pass".

Applying the SChM to the interpretation of traffic accidents, the following interpretation can be given: a traffic accident is the result of the overlap in time and point of the road network of dangerous driver actions, road management problems, faulty traffic supervision and so-called hidden conditions (holes in the "Swiss cheese") (Fig. 2).

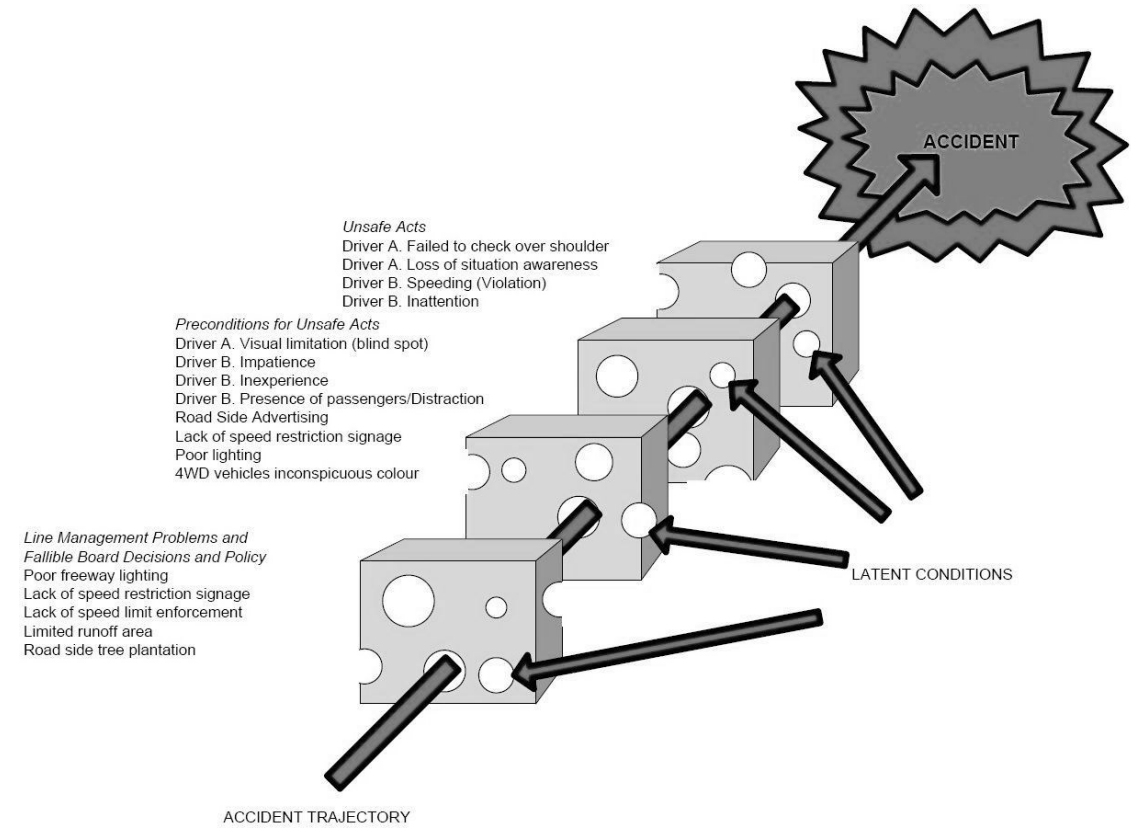

Fig. 2. Swiss Cheese Model of accident causation [12-13] 
In a complex system, active errors are consequences, not causes - they are forced by various combinations of hidden conditions. Hence the conclusion that safety prevention in such a system should minimize the hidden conditions that are there. This leads to the seemingly paradoxical conclusion that the reduction of potential human errors in a transportation system is not the most important aspect of safety prevention. More important are actions to improve those characteristics of the complex (transport) system that increase the probability of active errors. The point is that resident pathogens should be removed from the system as early as possible. This requires the use of methods of proactive system management, which mandates the minimization of errors at the level of system design. In the case of transport systems - this includes the detection and elimination of errors occurring already at the stage of creating legislation for transport managers (administration) [10].

\section{DEFENCE IN DEPTH (ALSO KNOWN AS DEEP DEFENCE)}

Deep Defence Strategy consists in designing in the considered object (system, process) a chain of physical, technical, procedural and organizational protection that significantly improves its safety, [17]. Multiple safety barriers mean that a break in any of them is detected at the local safety level of the system and triggers the defense mechanisms of the system. The individual safety links of a system are usually presented as follows [15-16]:

1. process equipment: safe technologies and procedures that control the process;

2. safety systems: activate defensive actions when disturbances occur;

3. safety barriers: they stop (slow down) the accident chain;

4. safety zones: limit the consequences of an accident

The DDS strategy is so universal that it can be used to develop a variety of multi-level work process safety systems (initial-final, traffic, control) in any transportation system. It can therefore form the basis for the design and construction of a transportation safety management system.

\section{DETERMINED CHAOS THEORY. FRACTAL THEORY OF ACCIDENT OCCURRENCE}

Determined chaos theory deals, among other things, with time series that describe the patterns of appearance of certain types of accidents. These time series can be described using the concept of fractal dimension, and systems fall into determined chaos states, generating accidents in a "structural" manner [17]. Some technical systems generate undesirable effects through the accumulation of initially small errors. It turns out that traffic is a chaotic system, that is, very sensitive to small changes in initial conditions; in this case, the socalled "butterfly effect" works [18]. In busy traffic, the butterfly effect may arise, for example, as a result of incorrect driver behavior at some point in the road network, which after some time causes traffic congestion at another point in the road network. Mathematical and simulation models of the occurrence of transport congestion in this type of transport conditions have been built for several years. The concept of determined chaos has been used for some time to model and predict traffic accidents in road traffic taking place in dense roadstreet networks [19-20].

\section{Mental MOdels OF SAfETy}

These models were developed using so-called "mind mapping techniques" [21]. These techniques were used to identify the main components affecting production safety:

1. Style of management;

2. Perception of management;

3. Work;

4. Home;

5. Personal responsibility;

6. Safety management strategies;

7. Views on safety and production.

Subsequently, 40 "safety components" were identified. Six of the basic components of the "mental safety map" were shown to have both increasing and decreasing safety features. It turns out that the only component containing only safety-enhancing elements was management style.

Safety mental models are a useful tool for educating and promoting a culture of safety [22-23]. However, there is an open question: can the concept of mental models of safety be applied to identify the main causes of transport accidents and to transport safety education?

\section{DIALECTICAL NETWORKING THINKING}

One systems approach called Dialectical Networking Thinking, (DNT) is well known in management and education (including safety) [2425]. The DNT concept has been successfully used in management on Slovenian railroads [26]. According to Muley the author of $D N T$ - the sense of systems thinking provides the best implementation of human 
actions. A systems approach to a problem includes "inseparably" and "non-exclusively" all components and all relations between them. In practice, this is impossible, but it can provide an ideal pattern of action, against which it is always necessary to decide what "level of systemicity" is sufficient in a particular case.

A systems approach to management in general, and therefore also to transport safety management, depends among other things on the quantity and quality of information, as this determines the level of wrong decisions, which in turn influences the size of risks [3]. In management, many decisions are made on the basis of routine, normative analysis and intuition. Normative analyses concern executive levels (here intuition plays a small role), intuitive analyses concern upper ( executive, management) levels of management, where there is a lot of intuition in decisions - hence an important problem is the selection of managers. According to Tavcar, the "best" decisions at high (strategic) levels of management are based on: intuition (80\%), problem analysis (16\%), and routine (4\%). At the executive levels of the management system they are respectively [27]: intuition (2\%), problem analysis (35), routine (36\%), undefined (27\%). Research shows that intuition backed by knowledge and routine is particularly useful in crisis situations [28].

\section{TRANSPORTATION SYSTEMS AS COMPLEX SYSTEMS}

If we consider any type of transportation over a large area and over a long period of time, it can be interpreted as Complex Systems (CS). The definition of such systems is relevant here [29]: A complex system is a system in which the development is highly dependent on initial conditions or small disturbances, in which the number of independent interacting elements is large, or in which there are many possible paths for the development of that system.

In large transportation systems, there are both known forms of complexity [30]:

1. chaotic complexity;

2. organized complexity.

The first is derived from a very large number of elements (infrastructure elements, means of transport, human factors involved in the implementation and participation in transport). The second is derived from the "matter" of the system - in this case the work processes in transport systems; mainly the traffic processes. Safety depends on the strength of the functional links present in such systems. There are always loose coupling and tight coupling. The first are characteristic for decentralized and the second - for centralized (hierarchical) management structure. This leads to a paradoxical situation described by C. Perrow: "the system (organization) should have both the features of centralization and decentralization" [31].

Large transportation systems, are complex systems, as they have the following characteristics [4], [10]:

1. have difficult to define boundaries; these are ultimately determined by the purpose and scope of the research (e.g., they may be determined by the ability to observe system performance);

2. are open systems, according to the approach of cybernetics;

3. are systems with memory; for they are dynamic systems;

4. are "nested" /embedded/ systems, i.e. their subsystems are themselves also complex systems; we are talking about subsystems of motion, control, initial-final (load) processes;

5. can "produce" emergence phenomena (emergence of new features);

6. interactions between elements of these systems are non-linear, which means that initially small transport incidents may cause large effects;

7. there are feedback loops in the interactions between elements, meaning that there are both negative and positive (reinforcing) feedbacks.

Transportation systems also meet other criteria of complex systems:

8. are inherently hazardous /intrinsically hazardous systems/;

9. contain mixtures of "hidden failures" ( e.g. faulty design conditions, are necessary conditions for accidents in the system);

10. the human experience in such systems is constantly changing;

11. changes generate new forms of failure;

12. safety is a system characteristic, not an individual component characteristic.

In transportation systems, there are a huge number of interactions between elements of the transportation infrastructure, the means of transportation, and the actions of the human agent. The products of these interactions are sometimes hardly predictable behaviors of system elements, especially human behavior in the spheres of decision-making and action. The final products are transport accidents and congestion the main negative effects of transport NET [3]. 


\section{TRANSPORTATION SYSTEMS VS. HIGH RELIABILITY ORGANIZATIONS}

In 1984, a group of researchers at the University of California, Berkeley initiated research on complex systems, which were given the name High Reliability Organizations, (HRO) [32-34]. The point is that there are systems that have highly hazardous technologies as an integral part of them, and yet serious accidents hardly happen there. These are systems where mistakes and failures can have catastrophic consequences for people and the environment. We are talking about nuclear power, chemical industry, management systems in passenger aviation, maritime industry. Thus, HROs are systems in which disasters are avoided and where so-called "normal accidents" are expected (concept introduced by C. Perrow) due to many risk factors and complexity of such system.

How can an HRO be most simply defined? According to $\mathrm{K}$. Roberts, it can be done by answering the following question: how many times could such an organization fail without causing catastrophic consequences? If the answer is: tens of thousands of times, then we are dealing with an HRO [32]. The key term "fail" here refers to errors and malfunctions that can happen in such a system, and yet, there will be no big consequences.

One may ask: are large transport systems which are after all complex systems - also HRO systems? Can safety management in road transport systems then be carried out using the philosophy and methodology applied in High Reliability Organizations? The answer is the following: large transport systems can be sometimes exemplifications of HRO systems; it is mainly about the functioning of transport in the conditions of crisis management, as well as the transport of dangerous goods. In general, however, road transport could not be classified as an HRO system for two fundamental reasons:

1. the potential consequences of single road transport incidents are almost never catastrophic; of course, the extent of losses is catastrophic when road accidents are considered over longer periods of time

2. road accidents are statistically frequent events.

\section{NORMAL ACCIDENT THEORY.} SYSTEM ACCIDENTS

The central thesis of Charles Perrow's Normal Accident Theory (NAT) is [35]: Accidents in complex organizations (...) are unavoidable. This is also exactly how road accidents must be understood on a global scale: they are unavoidable. Therefore, there is only one rational strategy left for improving road safety - eliminating fatal and serious accidents. This, of course, has been known for years (for example, the Swedish program "Vision Zero" - referring to fatal accidents with pedestrians in urban traffic). But it was stated decades ago by the creator of $N A T$, only that in a more general perspective.

What Perrow referred to as normal accidents or ordinary accidents, he also called, and others later called: systemic accidents or organizational accidents. According to [36] these are: unexpected interactions with multiple failures (failures) in a complex system. Perrow's rather pessimistic thesis about the unavoidability of accidents in complex systems has an alternative; supporters of the "high reliability point of view" argue that good design, and effective management in such systems can significantly reduce the probability of accidents [30], [34].

Perrow also analyzed risk in complex systems. It is the result of possible interactions between factors and elements of complex socio-technical systems. According to Perrow, whether a system can be considered simple or complex-depends on the number and type of interactions in these systems. Simple systems are those in which simple interactions prevail - that is, predictable - such as in a set of dominoes. Systems are complex if complex interactions predominate - that is, unpredictable interactions that come from an accumulation of factors or aspects that, taken separately - appear to be free of risk. The emergence of complex interactions initiates unpredictable system behavior that develops so rapidly that the system operator no longer understands the situation created, making it irreversible and leading to a system accident. It is this aspect of safety that Ch. Perrow emphasizes when he says that "accidents in a complex system are unavoidable." System accidents are the cumulative effects of socalled common-mode failures that form in a system due to unknown feedbacks between system components.

A wide definition of a systemic accident is given in the work [35]: "(...) It is no longer just the result of an unfortunate combination of passive and hidden negligence with active and direct defects, no longer just the result of a specific combination of human errors and material defects. The accident is (...) rooted in the history of the organization: a series of decisions or lack of decisions; the 
development of an organizational, institutional and cultural context that interferes with the system in the future; the progressive degradation of conditions or factors that are internal in the organization; a few specific events that have a great impact on the life and operation of the socio-technical system, creating an adverse situation: an area into which the accident (or incident) can invade and develop. (...) an accident goes through an incubation process. The incubation period can be long".

The frequency of system accidents depends on many aspects of a complex system, but most importantly it depends on:

- interactive complexity;

- tight coplings between interactions in the system. This second characteristic makes the system highly interdependent, that is, a change of one part of the system can quickly affect the state of other parts and the whole system.

It should be mentioned that Perrow's theory has contributed to a change of philosophy in the design and exploitation of complex systems, as well as in the study of safety and reliability of such systems. The attention has started to be paid to the risk aspects of accidents due to complexity and the presence of strong interactions in such systems [44].

A research postulate can be made here to verify the working hypothesis on the frequency of systemic accidents in road transport, i.e. to investigate whether it depends on interactive complexity and strong linkages in large road transport systems as well as in integrated transport systems. Great relevance would be given to possible "transport interpretations" of systemic accidents, known from other areas of technology [36-38].

For a large road transportation system to meet the "strong linkages" criterion, it would need to have the following characteristics [35]:

- most work processes are time-dependent, i.e., the functioning of the system cannot be stopped while waiting for corrective interactions to occur;

- specific and unchanging sequences prevail, such that event $A$ always leads to event $B$;

- the system is inflexible, i.e., it is planned in such a way that there is only one way to achieve the final goal;

- the system has a small room for manoeuvre, i.e. the quantities processed must be in planned quantities, the system's resources cannot be replaced by others, quick (ad hoc, temporary) changes to the system's tools are not possible.
It seems that only the first criterion can be met by any road transport system. In contrast, a dangerous goods transport system would mostly meet these criteria [39].

Perrow's Paradox. Risk in many modern engineering systems depends on the strength of the functional links present in such systems. There are always loose ties and strong ties. The first are characteristic for decentralized and the second for centralized (hierarchical) management structure. This leads to a paradox-because a well-functioning system (organization) should have both the characteristics of centralization and decentralization [36]. It turns out that centralized control is necessary during normal operation, while the ability to improvise is necessary in critical situations. It is therefore imperative that such systems have the ability to switch from a strict hierarchy to the decentralized, rapid structure needed in critical situations - something that can be used in building a transportation safety management system.

\section{SAFE SPACE OF ACTION}

J. Rassmussen introduced the concept of "safe action space" which he defined through risk analysis at the design stage of a specific real system [39]. The safe action space is contained between three boundary lines (Fig. 3):

1. boundary of unacceptable work load;

2. boundary of economic failure;

3. boundary of safety regulations.

R. Amalberti used the results of J. Rasmussen's research and described the concept of "the paradoxes of almost totally safe transportation systems" [40], (Fig. 4).

In practice, every system strives to achieve greater efficiency and increase the benefits of individual people working in such a system. As a result of such an aspiration - a new safety space goes beyond the limits defined in the initial (design) space. This new safety space is characterized by smaller margins of incident and accident risk and an increase in violations of regulations and standards.

A safety trap is created in that continued simple strategies to defeat violations by setting more and more rules result in increased reluctance and ambiguity to report incidents in the system, which reduces the quality of risk monitoring and which ultimately increases the risk of accidents. Amalbertii calls this effect the paradoxes of almost totally safe transportation systems and applies it primarily to the overall transportation system. The safe space of action concept may prove useful for analyzing the limits of transportation safety. 


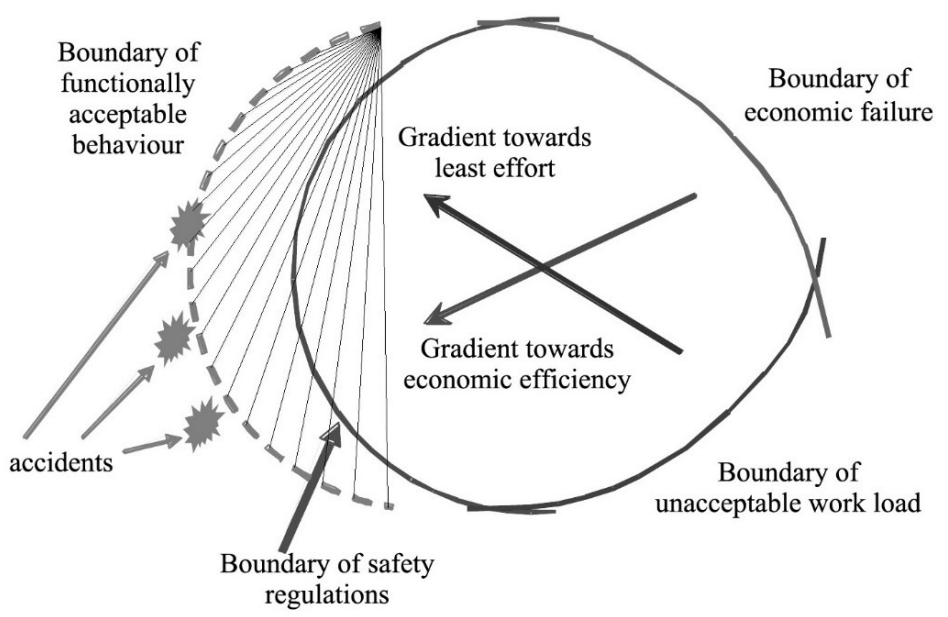

Fig. 3. Boundaries of safe operation [41]

Migration
to maximum
individual benefits

\section{INDIVIDUAL BENEFITS}

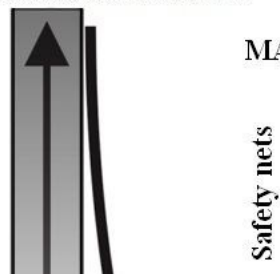

\section{MARGINS}

Area of violations \& deviances

:

$$
\text { : }
$$

Operational self stabilised space of action, with

of action, with
better performance,

more individual

more individual

benefits, and still

safety

safety

$\because$

Incidents

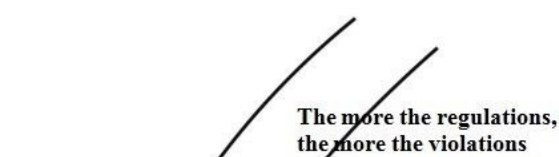

the pore the violations

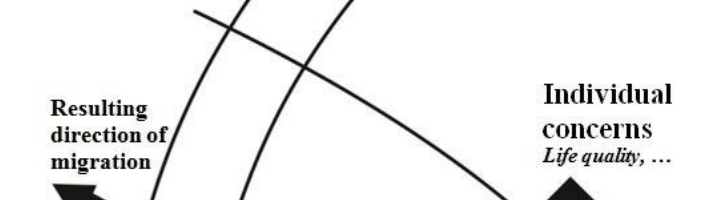

irection of

concerns

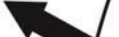
Life quality, ...
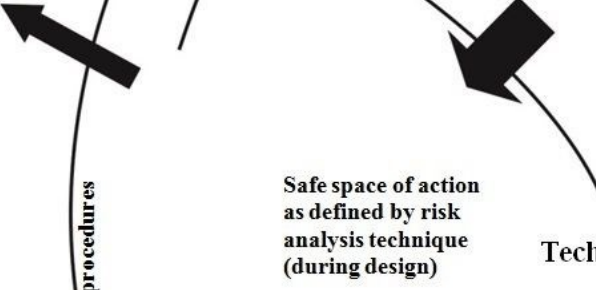

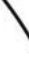

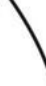
(during design)

Technology . 


\section{SAFETY VERSUS SYSTEM PRODUCTIVITY. "2P" DILEMMA OF SYSTEM MANAGEMENT: PRODUCTION VERSUS PROTECTION}

An issue from the same thematic area is one of the important management dilemmas, i.e. the "two P's dilemma", so called in the English literature [43]. It is about maintaining a balance between production $\mathrm{P}$ and safety in the sense of protection $\mathrm{P}$. The decisive influence on such a management balance is the policy of resource allocation. Simplifying somewhat: if too much attention and resources are devoted to the production sphere, the risk of accidents in the system increases; conversely, shifting the emphasis of management towards the safety of the system can lead to bankruptcy in the economic sense. Between these extremes is an area called "safety space". It defines a certain "balance area" that must be known and respected in system (organization) management. The main way to solve the above dilemma is risk management, which is sometimes referred to by the synonym "risk balancing". It is a management that has two risks in mind: the risk of bankruptcy and the risk of catastrophe.

"Production" can be interpreted differently, hence the "two P's dilemma" model can be implemented in various real systems. This aspect can also be found in transport systems in general and in road transport in particular. Each transport system can be described summarily in terms of two "effect-products":

1. transport performance;

2. transport safety (Fig. 5).
Contractual areas $A_{s}, A_{p}$ correspond - in the context of risk management - to risk levels known for example from the ALARP criterion, (As Low As Reasonably Practicable).

$A_{s}$ - level of unacceptable risk, i.e. such, where the individual risk of death (as a result of exposure to hazards in a particular transport system) is unacceptable; in principle it is the level of $10^{-4}$ [1/year]);

$A_{p}$ - low transportation performance is matched by (costly to maintain) low transportation risks; generally this level of individual risk of death starts at a value of $10^{-6}$ [1/year].

Managing such "products" in transportation systems is difficult because it requires making compromise decisions. Hence the dilemma: what is more important in road traffic? Is the efficiency of road networks and the fluidity of traffic streams, resulting in less time loss and resulting lower transport costs? Or the absolutely preferred safety of road users? Traffic safety may be a constraint on traffic system efficiency when considering shortterm (operational) traffic management horizons. In contrast, it may be one of the management objectives in the strategic management vision.

\section{GEYSEN'S THEORY. KUHLMAN'S SCHEME FOR SAFETY RESEARCH}

One form of discipline integration is clustering, when some single idea becomes the axis of interest for several disciplines. This idea may be a phenomenon, a problem, a geographical area, others. Specialists from different disciplines study a common topic from the perspective of their own disciplines. This is how a "tied discipline" is formed.

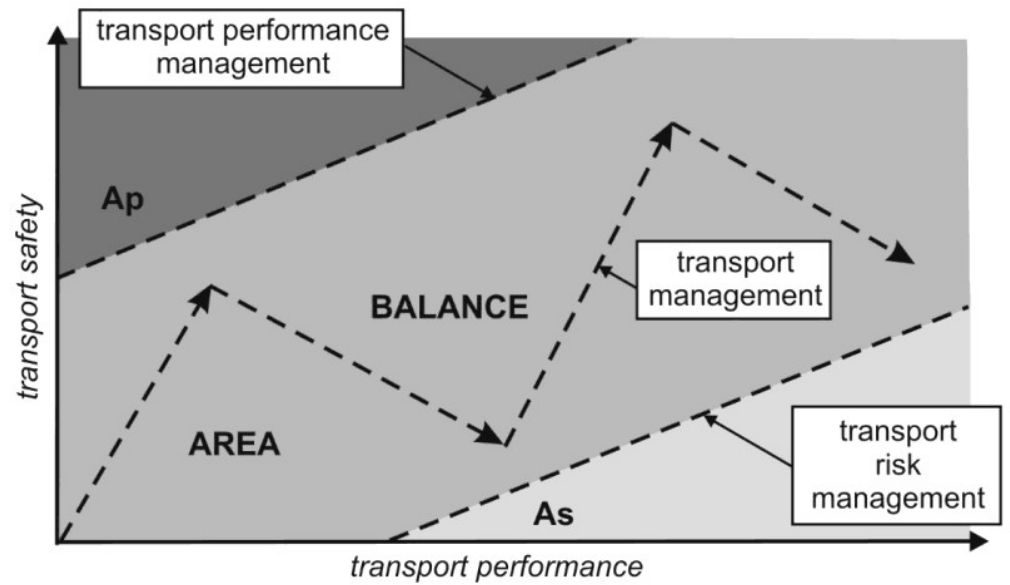

Fig. 5. A transportation interpretation of the „two P's dilemma” and safety space 
An example of "tying" are area studies, in which the problems of a certain geographical area are studied. It seems that such a knotty idea might be "transportation safety". A thesis can be formulated: "transportation safety" is a nodal idea that binds the studies of different branches of transportation. This is interdisciplinary research, without establishing any general paradigm" [43]

\section{FOUR LEVELS OF SAFETY PROBLEMS}

W. Geysen stated the following thesis: "(...) safety problems in different fields are very often of the same nature and can be formalized in the same way. This has given rise to what is now called safety science" [44]. This simple yet deep insight allows for the use of valid analogies, theories, and safety models to study transportation safety problems. In seeking legitimate analogies, researchers must keep in mind the specifics of transportation, and road transportation in particular.

Safety of any facility can be considered on 4 levels [44]:

1. "Safety philosophy": establishing safety and loss criteria.

2. Ways and methods that can be useful for improving safety.

3. "Safety technology": techniques to improve safety.

4. "Safety policy": compilation of knowledge and practice of levels 1, 2, 3.

\section{KUHLMANN'S SCHEME OF SAFETY RESEARCH}

Kuhlmann's scheme of safety research. In his definition of safety research objectives A. Kuhlman says [45]: "The main task of safety analysis should be the systematic study of the relationships between accidents, their consequences, causes and the probability of their occurrence. On the basis of this knowledge - as a second step, as it were effective accident prevention methods must be found".

Kuhlman's definition gives rise to several key questions that are also legitimate in transportation safety research:

1. What events should be considered significant?

2. Which events can be avoided by changes in the management structure?

3. What events cannot be completely excluded and with what frequency should they be expected to occur?

4. What type and extent of effects will these events have on people, technology, and the environment now and in the future, and what precautions should be taken?

From these key questions arise research directions such as:

- risk valuation according to the principle: how safe is safe enough?

- developing methods for forecasting and hazard monitoring techniques;

- development of accident genesis methods;

- development of protection and rescue systems.

\section{CONCLUSIONS}

The article shows some concepts, models and theories of safety known from research and applications in various fields of technology and suitable for use in the field of transport. One cannot aim at minimizing the risk of transport accidents in isolation from the related: the risk of growth in transport congestion and the risk of environmental degradation.

These risks are always associated with efforts to increase transportation efficiency, which depends on effective transportation management in the context of achieving three transportation objectives:

1. Ensuring high transportation workload.

2. Ensuring minimum nuisance to the environment

3. Ensuring the maximum level of safety.

Effective management of transport safety is possible when it is management by objectives, a kind of systematic management. A well-known principle of such management is that safety management relating directly to the size of the acceptable risk is most often referred to as risk management. In line with what has been written above, this principle should be extended and specified as follows: transport safety management relating to the magnitude of the jointly acceptable transport accident risk, environmental risk and the risk of increasing transport congestion - is referred to as overall (systemic) transport risk management, [3].

The main thesis that is the basis of the transport risk management methodology can be formulated as follows [4]: The principals and general methodology of risk management are the same for transportation as for other areas of technical human activity. Hence, the transportation risk management process has the same phases and is described with similar terminology as for other industries. What is specific to transportation is contained in the entire subject "superstructure" of the risk management process.

The older methodology of road safety management, but with an extension to any mode of transport, used a media shorthand called the "3E principle" (Education - Engineering- Enforcement). Later, the fourth E (Encouragement) was added, 
and for some time now, the fifth $E$ (Evaluation) has been written about. Thus, the new $5 E$ paradigm is a fact, as are the extended criteria of transport safety methodology.

There are many major challenges facing transportation safety research. One of them is the need to explore and strengthen synergies between subjects responsible for the level of transport safety. This involves balancing active transport policy and spatial planning due to the fact that there are strong links in this area, for example the relationship between mobility and spatial planning investments.

An important and difficult problem is the integration of risk management methods in all modes of transport and at their "interface". Many solutions have been obtained by trial and error. But a methodological framework and a universal standard for integrated transport safety management are needed. Of course, there are important differences in safety management between transport modes. Basically, they relate to the great dissimilarity of road transport from the other transport modes. It therefore seems that the future belongs to the "1+3" concept of an integrated transport safety system.

\section{OGÓLNE KONCEPCJE BEZPIECZEŃSTWA WYKORZYSTYWANE W TRANSPORCIE}

W artykule przedstawiono wybrane koncepcje, modele oraz teorie bezpieczeństwa znane $z$ badań i zastosowań w różnych obszarach techniki i nadające się do wykorzystania w dziedzinie transportu. W szczególności zwrócono uwagę na poznawczo obiecujące w dziedzinie bezpieczeństwa transportu a stosunkowo mało tutaj wykorzystywane koncepcje badawcze, jak: teoria normalnych wypadków /Normal Accident Theory/ autorstwa Ch. Perrowa, model „sera szwajcarskiego” /,Swiss cheese model”/ J. Reasona, koncepcje „bezpiecznej przestrzeni działań” /,safe space of actions”/ J. Rasmussena oraz R. Amalbertiego, koncepcja tzw. organizacji dużych (wysokich) niezawodności /High Reliability Organizations/, czy interpretacje systemów transportowych jako systemów złożonych/complex systems/.

Zasadniczym celem artykułu było przedstawienie kilku ważnych ogólnych koncepcji bezpieczeństwa i pokazanie, że można je wykorzystywać do modelowania bezpieczeństwa w dziedzinie transportu. Z artykułu wynika, że tzw. teza Geysena pozwala na opracowywanie uzasadnionych analogii bezpieczeństwa pomiędzy systemami transportu, a takimi systemami techniki, które mają większe osiągnięcia naukowe i inżynierskie w dziedzinie bezpieczeństwa.

Słowa kluczowe: systemy transportowe, teoria normalnych wypadków, "model sera szwajcarskiego", przestrzeń bezpieczeństwa, Organizacje Wysokiej Niezawodności, systemy złożone

\section{REFERENCES}

[1] Compes P. C. (1990) Fazit un Integration Konzept und Praxis der Siherheitswissenschaft. Proceedings of $1^{\text {st }}$ World Congress on Safety Science. Köln, Teil 2

[2] BS 292 (1991) British Standard EN 292: Safety of Machinery Basic Concepts, General Principles for Design

[3] Szymanek A. (2012) Teoria i metodologia zarządzania ryzykiem w ruchu drogowym. Politechnika Radomska, Radom 2012; ISBN 97883-7351-505-5

[4] Szymanek A. (2020) "System Approach in Road Safety Studies". Communications - Scientific Letters of the University of Zilina, 22(4), 201-210. https://doi.org/10.26552/com.C.2020.4.201-210

[5] Hermitte, T. (2012) Review of Accident causation models used in Road Accident Research of the EC FP7 project DaCoTA, D5.9, 21.09.2012

[6] Abraha H.H., Liyanage J.P. (2015) "Review of Theories and Accident Causation Models: Understanding of Human-Context Dyad Toward the Use in Modern Complex Systems". In: Lee W., Choi B., Ma L., Mathew J. (eds) Proceedings of the 7th World Congress on Engineering Asset Management (WCEAM 2012). Lecture Notes in Mechanical Engineering. Springer, Cham. https://doi.org/10.1007/978-3-319-06966-1_2

[7] Heinrich H. W (1931) "Industrial accident prevention: a scientific approach". McGraw-Hill. OCLC571338960; [Heinrich's domino model off accident causation - https://risk-engineering.org/ /concept/Heinrich-domonos]

[8] Hollnagel E., (2009) Safer Complex Industrial Environments: A Human Factors Approach. CRC Press. ISBN 978-1-4200-9248-6

[9] Hang D., Xi N. (1998) "Accident causation and prevention theories. In: Progress In Safety Science and Technology". Proceedings of the 98 International Sympodium on Safety Science and Technology. Ed. Zeng Qingxuan et al. Science Press. Beijing/New York, p. 62

[10] Szymanek A., (2019) "The concept of using SCh-M and LTSA models to identify management gaps in the Polish road safety system". Proceedings of the $23^{\text {rd }}$ International Scientific Conference. TRANSPORT MEANS 2019. Sustainability: Research and Solution. Part III, 2019, pp. 1170-1174; ISSN 1822-296 X (print); ISSN 2351-7034 (on-line)

[11] Reason J. et al. (1990) "Errors and violations road: A real distinction?" Ergonomics, 33, pp. $1315-1322$ 
[12] Reason J. (1997) Managing the Risks of Organizational Accidents. Aldershot: Ashgate

[13] Salmon P., Regan M., Johnston I. (2006) "Human Error and road transport: Phase two A framework for an error tolerant road transport system". Monash University Accident Research Centre Report Documentation Page. Report No. 257; ISBN 0732623278

[14] Cotton-Barratt O, Daniel M, Sandberg A. (2020) "Defence in Depth Against Human Extinction: Prevention, Response, Resilience, and Why They All Matter". [published online ahead of print, 2020 Jan 24]. Glob Policy. 2020. https://doi.org/10.1111/1758-5899.12786

[15] Rasmussen J. (1990) "Safety research and the technological development". Proceedings of $1^{\text {st }}$ World Congress on Safety Science. Köln. Teil 1, pp. 364-377

[16] Hollnagel, E. (2004) Barriers and accident prevention. Hampshire. England: Ashgate Publishing Ltd.; ISBN 978-1138247352

[17] Mandelbrot B. (1965) "Self similar error clusters in communication systems and the concept of conditional stationarity". IEEE Transactions on Communication Technology. 13(1), 71-90; https://doi.org/10.1109/TCOM.1965.1089090

[18] Lorenz E.N. (1963) "Deterministic non-periodic flow". Journal of the Atmospheric Sciences. 20, pp. 130-142; https://doi.org/10.1175/1520-0469(1963)020 $<0130$ :DNF>2.0.CO;2

[19] Frazier Ch., Kockelman K. M. (2004) "Chaos Theory and Transportation Systems: An Instructive Example". Transportation Research Board 83rd Annual Meeting, January 12, 2004, Washington D.C.

[20] Jing, Kecen and Liao, Wen-Chi (2017) "The Butterfly Effect of Transport Network Connectivity and Welfare Implication" (December 17, 2017). http://dx.doi.org/10.2139/ssrn.3089360

[21] Buzan T. (1993) The Mind Map Book. London: BBC Books. ISBN 978-0563363736 \& Buzan T., Buzan B., (2003) The Mind Map Book, 3 Rev Ed edition. BBC Active. ISBN 9780563487050

[22] Cooper D. (1998) Improving safety culture. A practical guide. John Wiley \& Sons Ltd.

[23] Tee Tze Kiong, Jailani Bin Md Yunos, Baharom Bin Mohammad, Widad Binti Othman, Yee Mei Heong, Mimi Mohaffyza Binti Mohamad (2012) "The Development and Evaluation of the Qualities of Buzan Mind Mapping Module", Procedia - Social and Behavioral Sciences,
Vol.59, 17 October 2012, pp. 188-196; https://doi.org/10.1016/j.sbspro.2012.09.264

[24] Mulej M. (1992) "Teorije sistemov. Univerza v Mariboru", Ekonomsko-poslovna fakulteta, Maribor, pp. 18-21

[25] Zdenka Zenko, Bojan Rosi, Matjaz Mulej, Tatjana Mlakar, Nastja Mulej (2012) "Genera Systems Theory Completed Up by Dialectical Systems Theory". Research project that is supported by the Slovenian Public Agency for Research as a basic research project: 1000-09212173, in 2009-2012. Part of this research project was presented at the International Conference on Complex Systems, ICCS12, Agadir, Morocco, 5-6 November 2012 https://doi.org/10.1002/sres.2234

[26] Rosi B., Mulej M. (2005) "With More Dialectic Networking Thinking the Slovenian Railway Traffic System Can Become More Competitive in Europe", Organizacija 38, pp. 169-175

[27] Tavcar I. M. (2002) "Strateški management". Univerza v Mariboru. Ekonomsko-poslovna fakulteta. Inštitut za razvoj managementa. Birografika Bori, Izola, p. 9

[28] Kramberger T., Rosi B. (2007) "Do Managers have Enough Quality Information for DecisionMaking". Organizacija, Volume 40, Number 5, pp. 207-217

[29] Whitesides G.M., Ismagilov R.F. (1999) "Complexity in Chemistry". Science 1999, 284 (5411), pp. 89-92, ISSN 1095-9203

[30] Turner J. R., Baker R. M. (2019) " Complexity Theory: An Overview with Potential Applications for the Social Sciences". Systems 7(1), 4; pp. 1-22. https://doi.org/10.3390/systems7010004,

[31] Perrow, C. (1986) Normal accidents: living with high risk technologies. New York: Basic Books, 1986. ISBN 978-0691004129

[32] Roberts K. H. (1990) "Some characteristics of high-reliability organizations". Organization Science [online]. 1990, 1(2), p. 160. ISSN 10477039, elSSN1526-5455. https://doi.org/10.1287/orsc.1.2.160.

[33] Lekka CH. (2011) High reliability organisations a review of the literature [online]. RR899 Research Report. London: Health and Safety Executive. www.hse.gov.uk/research/rrpdf/rr899.pdf

[34] Enya A., Pillay M., Dempsey S. (2018) "A Systematic review on high reliability organisational theory asa safety management strategy in construction“. Safety [online], 4(1), 6. elSSN 2313-576X. https://doi.org/10.3390/safety4010006 
[35] Perrow C. (1984) Normal Accidents: Living with High-Risk Technologies. New York: Basic Books

[36] Hopkins A. (2007) "The Problem of Defining High Reliability Organisations". Working Paper 51, Faculty of Arts and National Research Centre for OHS Regulation, Australian National University

[37] Almeida I. M. (2006) "Systemic approach to accidents and occupational health and safety management". Interfaces - A Journal on Integrated Management of Occupational Health and the Environment [online]. Art 1; ISSN 1980-0908

[38] Le Coze J.-CH. (2015) "1984-2014. Normal accidents. Was Charles Perrow right for the wrong reasons?" Journal of Contingencies and Crisis Management [online]. 2015, 23(4), pp. 275-286. https://doi.org/10.1111/1468-5973.12090

[39] Rasmussen J. (1997) "Risk management in a dynamic society: a modelling problem", Safety Science, Volume 27, Issues 2-3, 1997, pp. 183-213. ISSN 0925-7535, https://doi.org/10.1016/S0925-7535(97)00052-0

[40] Amalberti R. (2001) "The paradoxes of almost totally safe transportation systems". Safety
Science, Vol., Issues 2-3, 2001, pp. 109-126, ISSN 0925-7535;

https://doi.org/10.1016/S0925-7535(00)00045-X

[41] Leveson N.G. (2002) A New Approach To System Safety Engineering. Aeronautics and Astronautics Massachusetts Institute of Technology; Available from: http://ocw.mit.edu

[42] Leveson N.G. (2004) "A New Accident Model for Engineering Safer Systems". Safety Science, 42(4), pp. 237-270

[43] Szymanek A. (2018) "Theory of complex systems and the high reliability organization concept in transport safety modeling". In: 22nd International Scientific Conference Transport Means 2018, Proceedings. Part II. 2018. ISSN 1822-296X, elSSN 2351-7034, pp. 828-833

[44] Geysen W. J. (1990) "The Structure of Safety Science: Definitions, Goals and Instruments". Proceedings of $1^{\text {st }}$ World Congress on Safety Science. Köln, Teil 1, pp. 44-80

[45] Kuhlmann A. (1986) Introduction to Safety Science. Springer-Verlag, New York - Berlin Heidelberg - Tokyo. ISBN 978-1-4613-8596-7 